\title{
The Doctrine of Sufferance in the Library
}

IN RECENT years there has developed a $I_{\text {growing awareness among librarians that }}$ all is not well in the stacks. ${ }^{1}$ Confronted with an ever accelerating avalanche of printed matter against which present and contemplated library budgets seem pitifully inadequate bulwarks, librarians are being driven to a critical re-examination of their basic problem. At first, it seemed that they needed only to appeal for more funds; now it is all too evident that such an appeal, even in the unlikely event of its being thoroughly successful, could produce a stopgap only for the day. The situation is especially critical in the research libraries, which are bound by their philosophy to try to acquire everything remotely touching their field of interest and to hold all such acquisitions in perpetuity, even when no present defense of the books and documents can be made, on the premise that the most insignificant item of today may, by tomorrow's scholars, be proved to be the key that unlocks a world of intellectual excitement.

It would be bad enough if libraries had to contend only with the source material. But there are critical examinations of sources, and commentaries on the examinations, then commentaries on commentaries, followed by bibliographies of the commentaries, examinations, and sources. As if this were not enough, there are, finally, bibliographies of bibliographies. Redundancy raised to a power! The mind balks, ap-

\footnotetext{
1 Kirkpatrick, Leonard Henry. "Does Your Library Lack a Plan?" Library Journal $71: 782-88$, June 1 , 1946 .
}

palled at taking the next logical step.

It becomes increasingly clear that we are now confronted not with the physiology of libraries but with their pathology. This exuberance of multiplication suggests to the observer not so much normal growth as it does the existence of an insidious bibliographic neoplasm. What can we do about it? . Is there a cause? If we can find a cause, can we, perhaps, eliminate it?

To search for causes is defensible on methodological grounds, though when one is dealing with human affairs the psychological roots of this activity do not always seem completely noble. We feel we must blame someone. In the present instance there is considerable temptation simply to put the blame on the librarian, a temptation to which some ${ }^{2}$ have yielded. Even granting that the search for a whipping-boy is worth while, it seems questionable if the librarian can be held accountable for the stew we are in. The intellectual fare available is too much and too rich for our mental digestive system to cope with, but the librarian can hardly be blamed. His relationship to the ultimate pâté de foie gras is that of the goose; the gaveur des oies is the scholar.

There have been attempts to "do something about it." Among librarians, Fremont Rider has attracted the most attention with his proposal ${ }^{3}$ to reduce books photo-

\footnotetext{
2 Hardin, Garrett. "The Last Canute." Scientific Monthly 63:203-08, September 1946.

${ }^{3}$ Rider, Fremont. The Scholar and the Future of the Research Library. New York, Hadham Press,
} r944. 
graphically to the size of index cards, and thus conserve space. The basic idea behind Rider's proposal has been developed even further by the physicist and gadgeteer Vannevar Bush, ${ }^{4}$ who points out that it will soon be possible to reduce documents and recorded data to microscopic size; to classify them and store vast quantities of them in an instrument of desk size; and to recall, almost instantly, any classification to the "reader," to be used, perhaps reclassified, in other ways; and finally stored away again. Unquestionably, Bush's proposal is appealing. It might even mean the ultimate disappearance of libraries.

At first glance, proposals of the BushRider type would seem to solve the problem of research libraries. A moment's reflection, however, will show that they attack the problem in only a superficial way. They assume that if we can reduce the bulk of the individual items sufficiently, we need not worry about the number of items nor about the rate at which the number increases. To make such assumptions, implicitly or otherwise, is to regress scientifically to the days before Darwin and Malthus.

Perhaps the point can be made clear by an example from bacteriology. Clostridium botulinum, the bacterium which causes a very unpleasant sort of food poisoning, is only one-twenty-five-thousandth of an inch long. It multiplies, however, exuberantly, each cell dividing to form two cells in less than half an hour, under favorable conditions. Suppose, now, that someone developed a passion for Clostridium, became a clostridiaphile, as it were, and decided to save all his little clostridia, nourish them carefully, and never throw out a single cell. If he started his collection modestly on Monday morning with a single bacterial cell, by Tuesday he would have a mass of cells

"Bush, Vannevar. "As We May Think." Atlantic Monthly r76:10r-08, July r 945 . which would weigh over two pounds. By Wednesday morning he would have over a million tons of bacteria; and before Friday, the weight of the bacteria would exceed that of the entire earth. Clearly, clostridiaphily is a passion not to be encouraged.

\section{Rate of Increase Sets the Problem}

The problems encountered in collecting any things which are constantly increasing in numbers can be put in mathematical language. ${ }^{5}$ But frank mathematics repels many people, and embarrasses the printer; the same point can be made here in the following words: the rate of increase in size of any collection (library) is determined by two things, to wit, the size of the individual items (books) and their rate of increase (rate of collection, etc.). In the long run, the size of the individual items is of only minor importance. It is the rate of increase which sets the problem. If Mr. Rider is correct in his belief that the rate of increase in numbers of library books is a function which has no finite limit, then it won't matter particularly what we do about the size of the books. Even if we reduce them to the size of clostridium cells we will ultimately suffer a fate little different from that caused by too close association with Clostridium botulinum.

To become masters of our fate we must control the growth equation in one of two ways: either we must continually diminish the rate of increase or we must introduce what one might call a mortality factor and eliminate individuals whose procreation we have permitted. The growth of book populations shows considerable parallelism with the growth of human populations, and the problem of overpopulation suggests a Malthusian solution in both cases. There is,

"Lotka, A. J. "Population Analysis as a Chapter in the Mathematical Theory of Evolution." "In Essays on Growth and Form Presented to D'Arcy Wentworth Thompson. Edited by W. E. LeGros Clark and P. B. Medawar. Oxford, Clarendon Press, 1945.). 
however, this important difference required by our mores: in the control of populations of books, euthanasia is to be preferred to contraception, which is the reverse of the solution elected by what we like to call civilized populations of humans.

\section{Must Destroy Books}

Unless we are to attempt a totalitarian control of the genesis of written material, we must be willing to destroy that which is already in existence. This seems clear, and yet there are many who are unwilling to accept it, it is so contrary to our training. "Books are sacred," "monuments of the past," "depositories of the wisdom of the ages"- how often have we not heard these and similar clichés? Logically we may now realize that we must deny our long-held principles, but emotionally it is difficult to bring ourselves to the actions required.

This emotional bias is one of the reasons why we fight off the inevitable as long as possible. But there is another reason, equally effective, namely, the questions: How are we to eliminate? Which books or documents shall be thrown to the fire? The problems of collecting are difficult; the problems of uncollecting are difficulty squared. Collecting, given enough money, is a relatively passive occupation in which one needs only to yield to the strongest pressures. Uncollecting is a dynamic, difficult, discriminative activity in which one can expect to be opposed at every point by outside pressures of the greatest volubility. Librarians, as a group, are not pugnacious; such a trait has not, in the past, been of selective value in the libraries. Now, suddenly, it would seem that librarians must develop this trait if they are to survive and properly fulfil their function. It is a most difficult and unpleasant situation. Collecting, cataloging, storing forever-this is the path of least resistance.
There are times when the enemy is more easily met en masse than individually. This is such a time. If the librarian must fight for every single book eviction, he will, in the end, give up the fight altogether. It is the individual who is on the defensive who is in the weak position. If the librarian is to win his fight he must somehow maneuver his opponents into the defensive position. This can be done in a rather simple manner, by a single change in the philosophy and modus operandi of libraries, as follows.

\section{Librarians Must Evict Books}

Let not the retaining but the evicting of books be automatic. Let no book remain on the shelves unless someone fights to keep it there. Let an undefended book be a condemned book. This must be accepted as the philosophy of the modern research library. Gone must be the static conception of the library as a storage organ, and in its place we must conceive of the library as a dynamic circulatory system, a channel through which books pass on their way from the publisher to the incinerator. The current is swift these days, and no book can long remain in the same place in the channel unless someone is fighting to keep it there. And the energy required for this fight is not to be furnished by the librarian; he is merely an aloof, and possibly slightly sardonic, observer of the foibles of men and their books.

No book remains in the library save on sufferance. This must be the basic principle governing libraries, at least college and research libraries. Small general libraries are a different problem, and will not be considered here. By "book," of course, we mean any printed matter that comes to the library, whether bound volume, pamphlet, catalog, theatre program, or holograph. If the sufferance philosophy is accepted, there remains only to set up the enabling machinery to achieve its ends. This should 
not be a difficult matter, but it is a technical one, and consequently impossible to bring to technical perfection in one jump. The suggestions which follow are intended only as suggestions. The detailed perfection of the machinery will require the services of experts.

Thinking in terms of a college library, let us suppose that one of the academic departments of the college, say Department $A$, requests a certain book. The book is bought and cataloged in 1947. At the time of cataloging a symbol is entered on its card which indicates that Department A requested it; and another symbol indicates the book is to come up for review five years later, in 1952 . When 1952 arrives the book is automatically put on the defensive. At this time a card with the name of the book is sent to Department $A$, with the request that one of the following categories be checked:

I. We defend the book. Retain all copies.

2. Retain one copy. Destroy duplicates.

3. No judgment. Refer it to [individual or department] for judgment.

- 4. No defense. Final bans should be published.

If Option 4 is checked, the name of the book is then entered on a list which is published from time to time and circulated to all departments. Publication in the bans would give other departments a chance to defend books related to their own fields. If Department B should defend a banned book, this fact would be entered on the bookcard, and the next time the book came up for judgment it would be referred to Department B.

For the book would come up again and again for judgment. The first two periods of sufferance might perhaps be five years each, then perhaps there should be a tenyear period, followed by four twenty-year periods. At the end of a hundred years, if the book were still in existence, it might be put on a hundred-year sufferance, indefinitely renewable (upon defense), but never extendable without defense.

\section{Results of System}

If this system were adopted in good faith, it would result in marked improvement to the circulatory system of a college library. Most novels would not survive beyond the first five years. Most textbooks would go out at ten years. The majority of monographs and reviews, at least in science, would be cast out at the twenty-year mark. Original research papers would be a more difficult problem, but even these could probably be destroyed after one hundred years, or at most after two hundred. When that much time has elapsed it is easier to make the discovery anew than it is to exhume it from the library. Mendel's work in genetics was uncovered after forty years, but only after at least three other investigators had independently rediscovered the same facts. True, if we had not had libraries, Mendel would not have received the credit properly due him. But would that have mattered, really?

This philosophy puts the burden of judgment squarely on the scholarly departments, which is where it belongs. The librarian's duty in a research library is that of a skilled technician, whose job it is to keep the circulatory machinery going. The quality of the material circulated is the responsibility of the departments served by the library. They must pick the books in the first place; and they should subsequently be responsible for reviewing them. Any department unwilling to assume this responsibility would be denied the right of making new purchases.

Difficulties will be encountered, of course. Sometimes a narrow-thinking department may sabotage the works by almost always 
checking Option I. Somehow the library must be given power to circumvent such lack of cooperation. Or, a department may not check Option 4 as often as it should. In time, the librarian would probably develop some sort of secret rule-of-thumb with which to check upon departments. If a department does not cooperate, the librarian may politely refuse to order any new books for it, pointing out that there can be no more shelf space until old material is discarded. Subjected to such pressure, most departments would undoubtedly find it possible to cooperate.

In general, less trouble will be experienced with science departments than with the departments dealing with the humanities. History departments, of course, will be particularly troublesome because of the widespread belief that all history is important. Special machinery may have to be set up to deal with this field, especially since so much of the research material here consists of masses of small items which were either not requested in the first place or were taken in as a lot, without individual examination. To avoid further antagonism, the subject will be dropped forthwith, though not without an earnest recommendation to historians that they read Bridgman's work ${ }^{6}$ before they come to the conference table to iron out their own peculiar problems.

Other contingencies will arise, but this is not the place to go into them. The attempt

'Bridgman, P. W. The Intelligent Individual and Society. New York, Macmillan, 1938. has been to present only a crude sketch of the machinery and to avoid dispute over details. Undoubtedly the bookcards that were mentioned would actually be part of some sort of punched-card system. Thus, it would be possible, in a few hours, to run through the cards of even the largest library and sort out the cards of the books coming up for trial. But this is a detail.

\section{Concept Will Not Please All}

Some librarians may be revolted by the new concept of their status in the scholarly world, but I believe this feeling will pass. It may seem at first that their new role is one with less power, and hence less attractiveness, but I think that in time, quite the reverse opinion will come to prevail. Certainly, taking from their hands the entire responsibility of judging books should make their lives less onerous. The judging of books is even now, in research libraries, less a coveted privilege than it is an unpleasant duty. The logic of the times demands that this duty be shifted to other shoulders. Some librarians, of course, may choose to continue to fight a rear-guard action against the hyperMalthusian forces; but ultimate defeat cannot be prevented unless the new philosophy is embraced. Such a reorientation of principles will not be the librarian's admission of defeat, but rather a statement of his intent to control his own domain. In the end, the doctrine of sufferance will make the librarian less a slave and more a master of the library to which he is attached. 